\title{
The SARS coronavirus E protein interacts with the PALS1 and alters tight junction formation and epithelial morphogenesis
}

\author{
Kim-Tat Teoh', Yu-Lam Siu', Wing-Lim Chan ${ }^{1 *}$, Marc A Schlüter ${ }^{2}$, Chia-Jen Liu ${ }^{3}$, S Malik Peiris ${ }^{1,4}$, \\ Roberto Bruzzone ${ }^{1}$, Benjamin Margolis ${ }^{3,5}$, Béatrice Nal ${ }^{1,6}$
}

From Institut Pasteur International Network Annual Scientific Meeting

Hong Kong. 22-23 November 2010

Intercellular tight junctions define epithelial apicobasal polarity and form a physical fence which protects underlying tissues from pathogen invasions. PALS1, a tight junction-associated protein, is a member of the CRUMBS3-PALS1-PATJ polarity complex, which is crucial for the establishment and maintenance of epithelial polarity in mammals. Here we report that the carboxyterminal domain of the SARS-CoV E small envelope protein (E) binds to human PALS1. Using co-immunoprecipitation and pull-down assays, we show that E interacts with PALS1 in mammalian cells and further demonstrate that the last four carboxy-terminal aminoacids of $E$ form a novel PDZ-binding motif that binds to PALS1 PDZ domain. PALS1 redistributes to the virion assembly site, where $\mathrm{E}$ is enriched, in SARS-CoVinfected Vero E6 cells. Ectopic expression of E in MDCKII epithelial cells significantly alters cellular polarity and induces formation of cysts with multiple lumens. We show that $\mathrm{E}$ expression delays formation of tight junctions and affects the subcelullar distribution of the apical and tight junction markers GP135 and ZO-1, respectively. We speculate that hijacking of PALS1 by SARS-CoV E plays a determinant role in the disruption of the lung epithelium in SARS patients.

\begin{abstract}
Author details
${ }^{1}$ HKU-Pasteur Research Centre, Hong Kong, Hong Kong SAR. ${ }^{2}$ Medizinische Klinik D, Universitätsklinikum Münster, D-48149 Münster, Germany. ${ }^{3}$ Department of Biological Chemistry, University of Michigan Medical School, Ann Arbor, Ml 48109, USA. ${ }^{4}$ Department of Microbiology, Li Ka Shing Faculty of Medicine, The University of Hong Kong, Hong Kong SAR. ${ }^{5}$ Department of Internal Medicine, University of Michigan Medical School, Ann Arbor, MI
\end{abstract}

${ }^{1}$ HKU-Pasteur Research Centre, Hong Kong, Hong Kong SAR

Full list of author information is available at the end of the article
48109, USA. ${ }^{6}$ Department of Anatomy, Li Ka Shing Faculty of Medicine, The University of Hong Kong, Hong Kong SAR.

Published: 10 January 2011

\section{doi:10.1186/1753-6561-5-S1-P79}

Cite this article as: Teoh et al:: The SARS coronavirus E protein interacts with the PALS1 and alters tight junction formation and epithelial morphogenesis. BMC Proceedings 2011 5(Suppl 1):P79.
Submit your next manuscript to BioMed Central and take full advantage of:

- Convenient online submission

- Thorough peer review

- No space constraints or color figure charges

- Immediate publication on acceptance

- Inclusion in PubMed, CAS, Scopus and Google Scholar

- Research which is freely available for redistribution
() Biomed Central 